\title{
Recognizing the limits: \\ sustainable development, corporate \\ sustainability and the need for innovative \\ business paradigms
}

\author{
Antonio Tencati - Stefano Pogutz
}

\begin{abstract}
Purpose of the paper: The study provides a theoretical analysis of the implications of sustainability in business, with a specific focus on the ecological dimension. In particular, we introduce key concepts from natural science and ecological economics into the field of management in order to highlight the limits that characterize the natural capital and our individual and organizational dependence on it.

Methodology: The paper draws upon a mix of literature review (management, ecology and ecological economics), action research and field studies.

Findings: The study presents the reasons for a profound transformation of the dominant business paradigm in order to address sustainability challenges. Furthermore, it introduces a conceptual framework to position and analyse corporate actions to manage environmental issues and identifies four areas of intervention and research as key drivers of transformational change.

Practical implications: By stressing the managerial importance of concepts like carrying capacity, critical natural capital, and ecosystem services and by pointing out the need for collaborative approaches, the paper advances innovative perspectives to analyse and develop sustainable business strategies and operations.

Research limitation: The paper shares the limits of conceptual works based on a deductive method. However, to address this limitation, the study is also supported and complemented by the empirical experience gained in more than two decades of fruitful collaboration with companies and institutions.

Originality of the paper: The study introduces concepts that are mainly developed in scientific disciplines. This provides an insightful contribution to the current debate on the real soundness of mainstream management theories and business practices, and to the quest for fitting alternatives.
\end{abstract}

Key words: carrying capacity; collaborative enterprise; critical natural capital; ecosystem services; limits of nature; sustainable development

\section{Introduction}

Our planet is becoming more fragile. The financial and economic crisis that started in 2007 is only the most visible signal of the unsustainability of the current pattern of development at the global level. The interdependency between human organizations and nature that is characterizing the current epoch has been labelled Anthropocene, a neologism introduced by the Dutch Nobel Laureate P.J. Crutzen (2002) to capture the magnitude of the 
sinergie Vol. 33, N. 96, 2015

quantitative shift of the impact of humans on the global environment. The majority of natural scientists converge in considering the anthropogenic pressure on ecological systems close to a scale where abrupt transformation can no longer be excluded. Some global trends, illustrated in Table 1, provide further context:

Tab. 1: Some unsustainable global trends

\begin{tabular}{|l|l|}
\hline Issue & Trend \\
\hline Planetary \\
boundaries & $\begin{array}{l}\text { Mankind has already transgressed three of the nine } \\
\text { interconnected planetary boundaries identified by scientists: } \\
\text { climate change, rate of biodiversity loss, and interference with } \\
\text { the global nitrogen cycle (Rockström et al., 2009). }\end{array}$ \\
\hline $\begin{array}{l}\text { Ecosystem } \\
\text { degradation }\end{array}$ & $\begin{array}{l}\text { The Millennium Ecosystem Assessment (MEA, 2005) points out } \\
\text { that, over the past 50 years, approximately 60\% (15 out of 24) of } \\
\text { ecosystem services have been degraded or used unsustainably. } \\
\text { These services are fundamental for the well-being of the current } \\
\text { and future human generations and other living species. }\end{array}$ \\
\hline $\begin{array}{l}\text { Climate change } \\
\text { and global }\end{array}$ & $\begin{array}{l}\text { The atmospheric concentrations of greenhouse gases have all } \\
\text { increased since 1750 due to human activity, reaching the level of } \\
\text { 391 ppm (part per million) and exceeding pre-industrial levels } \\
\text { by about 40\% (IPCC, 2013) in 2011. }\end{array}$ \\
\hline $\begin{array}{l}\text { Ecological } \\
\text { Footprint }\end{array}$ & $\begin{array}{l}\text { According to the Living Planet Report 2014 issued by the WWF } \\
\text { and the latest available data (until 2010), humanity's Ecological } \\
\text { Footprint, that is, our impact on the Earth, exceeds our planet's } \\
\text { biocapacity, that is, the area that is really available to produce } \\
\text { renewable resources and absorb CO } \\
\text { 2014). In parallel, the Global Living Planet Index shows a } \\
\text { consistent loss of biodiversity: in fact, between 1970 and 2010 } \\
\text { vertebrate species populations have decreased by 52\% (WWF, } \\
\text { 2014). }\end{array}$ \\
\hline Undernourishment \\
$\begin{array}{l}\text { Inequalities in wealth distribution are increasing: in 2014 only } \\
408 \text { million people (8.6\% of the world adult population) own } \\
85.3 \% \text { of the global wealth while only 35 million people (0.7\% } \\
\text { of the world adult population) control 44\% of the total wealth } \\
\text { (Credit Suisse AG Research Institute, 2014, p. 98). }\end{array}$ \\
$\begin{array}{l}\text { About one in eight people in the world (12\% of the world global } \\
\text { population) is estimated to be suffering from chronic hunger, } \\
\text { regularly not getting enough food to conduct an active life (FAO, } \\
\text { IFAD, WFP, 2013, p. 8; United Nations, 2013, p. 4). }\end{array}$ \\
\hline
\end{tabular}

Source: Authors' elaboration

The presented evidence points out that the world is facing a multiple (that is, not only financial but also economic, environmental, social, cultural, and institutional) crisis. After about thirty years of absolute dominance (Crouch, 2011), the mainstream business model, based on a narrow focus on monetary results, strong short-termism, and a disruptive competitive approach which benefits few (especially financial investors and top managers) at the expense of many (comprising society, local communities, ecosystems and ecosystem services, and future generations) is strongly criticized (Birkinshaw and Piramal, 2005; Ghoshal, 2005; Stiglitz, 2012; Tencati and Pogutz, 2011; The Economist, 2011). 
Several arguments have been used to explain this failure in terms of environmental and social results, exploring both the theoretical weaknesses

of the sustainable development (SD) concept and its pragmatic fragility (Sneddon et al., 2006). At the same time, in spite of the growing urgency of the trends illustrated above, the currently prevailing management theories and business practices do not even recognize the crisis of mainstream models and continue to foster selfish, highly competitive, unsustainable behaviours (Tencati and Zsolnai, 2014).

The present article aims to provide an insightful contribution to the current debate on the need for alternative business paradigms (Golinelli and Volpe, 2012; Pascucci, 2011) by introducing the key concepts of carrying capacity, natural capital, and ecosystem services derived from natural science and ecological economics while underlining the limits of "business as usual" approaches to environmental sustainability and opening new perspectives in order to identify how business can effectively pursue the goals of SD.

Thus, we first analyse the evolution of the SD idea, focusing in particular on the environmental challenge. After that, we carry on a twofold analysis, investigating deficiencies and challenges at the macro level and the major limits of the "corporate greening" approach. Then, we examine possible initiatives and actions that businesses can carry out to address environmental and social problems. Finally, we highlight structural changes in behavioural patterns and the innovative ways of doing business that are needed to face the sustainability challenge.

\section{Evolution of the sustainable development idea}

Starting from a strict ecological focus, the SD idea has been developed over at least the last four decades. Among the offered definitions, the most common and established is that provided by the World Commission on Environment and Development (WCED) chaired by Gro Harlem Brundtland, in 1987 at the opening of Chapter 2 of its Our Common Future report: "Sustainable development is development that meets the needs of the present without compromising the ability of future generations to meet their own needs" (WCED, 1997). Within this framework, the approach based on the "three pillars" of sustainability, which integrates economic, social, and environmental concerns into the SD model, has been consolidating since the Rio Conference in 1992, influencing both the institutional and corporate paths (Elkington, 1994). Furthermore, since the very beginning the issues of an equitable distribution of resources and benefits within society, and of the widening gap between industrialized and developing countries emerged, as central topics in the SD agenda.

In the decades following the publication of the Brundtland Report, the broad definition of SD advanced by the WCED became helpful in fostering a general awareness of the concept of sustainability, by calling on governments, corporations and society at large for a pragmatic response (Sneddon et al., 2006). Unfortunately, the primary drivers of the environmental degradation - material and energy consumption and a prevailing short-term view in the economic, social and political arenas - have grown worldwide and, as previously underlined, our current economy is deeply unsustainable. 
Sinergie Vol. 33, N. 96, 2015

\section{Carrying capacity, critical natural capital and ecosystem services: three concepts at the basis of ecological sustainability}

The definition promoted by the WCED has strengthened a view based on the principle that the economic, ecological and social pillars of SD are qualitatively and hierarchically equivalent and must be taken into account simultaneously. Although this approach can be considered desirable for several reasons, it has contributed to the marginalization of some specific ecological concepts that are critical conditions for sustainability and therefore need to be reconsidered within a more ecocentric paradigm. Among these concepts, carrying capacity (Costanza, 1991), the unsubstitutability of natural capital (Pearce and Turner, 1990), and the notion of ecosystem services (MEA, 2005) are crucial. A review can help build a better understanding of the interdependencies between businesses and the natural environment.

Carrying capacity can be defined as the population of an organism that an ecosystem can support, given the availability of resources within the ecosystem. This concept has been discussed in scientific domains like ecology, biology, demography, and economics; since the 1970s, the globalization of the environmental crisis has conducted to an intense and broad debate on the Earth's carrying capacity (Seidl and Tisdell, 1999). The importance of this concept in sustainability discourse is clearly expressed by Arrow et al. (1995, p. 520):

"The environmental resource based upon which all economic activity ultimately depends includes ecological systems that produce a wide variety of services. This resource base is finite. Furthermore, imprudent use of the environmental resource base may irreversibly reduce the capacity for generating material production in the future. All of this implies that there are limits to the carrying capacity of the planet".

As several scholars from the ecological economics community (Costanza, 1991; Daly, 1992; Martinez-Alier and Schupmann, 1987), from ecology (Holling, 2001; Levin, 2009), and other scientific domains (Capra, 1996) have pointed out for many years, the biosphere identifies the external limit of the system and contains the social and the economic spheres. This means that economic and social development has to proceed within the limits of the carrying capacity of our planet.

With regard to the notion of natural capital, this debate is grounded on the assumptions of neoclassical economics but has been extended by economists to other domains, including the natural and social sciences. A central issue in this discussion is the question of to what extent natural capital is substitutable and can be replaced with man-made capital (Ekins et al., 2003a). Different interpretations of this concept can be grouped into two main schools-weak and strong sustainability (Costanza, 1991; Pearce and Turner, 1990). The first approach posits that all forms of capital are equivalent and any loss in natural capital can be compensated by other forms (Solow, 1986). Therefore, weak sustainability allows the 
degradation of natural resources if they are covered through an increase in stocks of other forms of capital. The second approach assumes that some types of capital, for example, several forms of natural capital, have no substitute. According to this point of view, different forms of capital are complementary (Costanza, 1991; Costanza et al., 1997; Ekins et al., $2003 \mathrm{~b}$ ). Thus, these forms of capital must be preserved, independently of one another, and man-made capital should not be created to the detriment of natural capital.

Over the years, the debate on the limits to substitutability has led to the introduction of the concept of critical natural capital. Dodds (1995), quoted in Chiesura and De Groot (2003, p. 222), defines it as "those assets that have no ready substitutes, cannot be replaced, and have a unique contribution to present and future well-being". Ekins et al. (2003b, p. 169) identify critical natural capital as "natural capital which is responsible for important environmental functions and which cannot be substituted in the provision of these functions by manufactured capital". Examples of critical natural capital are several life-supporting environmental services, necessary for life production, including the ozone layer or the biosphere and the reduction of carbon dioxide by recombining carbon with other elements (Ayres, 2007). So, the uncertainty about the effects of our impact on critical natural capital should require the adoption of a "precautionary principle" in order to manage the relation between the ecological system and the socioeconomic one.

Ecosystems services consist in the benefits that human populations and organizations derive - directly or indirectly - from proper ecosystem functioning (Costanza et al., 1997). Ecosystems like forests or wetlands provide goods and services such as food, timber, climate regulation, water purification, genetic diversity, and medicines that support our well-being. The concept originated in the late 1970s/early 1980s, but started to generate large interest only in the 1990s with the publication of a landmark paper in the journal Nature by a multidisciplinary group of scholars (Costanza et al., 1997). The study estimated that the Earth's ecosystems provided between 16 and 54 trillion US\$ of free services to humans per year, and contributed to a broad and thoughtful debate on environmental sustainability. The popularity of this concept has been further advanced thanks to the massive effort that the Millennium Ecosystem Assessment, an initiative fostered by United Nations Secretary-General Kofi Annan in 2000 and concluded in 2005, carried out worldwide to evaluate the current status and trends of global ecosystem functioning (MEA, 2005). As previously underlined, the study offered a dramatic picture (MEA, 2005, p. 5). Moreover, it provided evidence that unhealthy ecosystems are incapable of supporting the same levels of services as in the past, with clear implications for nature's capacity to continue sustaining our growing economic activities indefinitely.

Carrying capacity and its related limits, critical natural capital, and ecosystem services are still controversial constructs that are complex to assess and measure. In any case, they are absolutely crucial in the SD framework. Our perspective on sustainability cannot be disconnected from the natural ecology view that many scholars acknowledge. These concepts remind us that continuing "business as usual" practices increase companies'
Antonio Tencati

Recognizing the limits: sustainable development, corporate sustainability and the sustainability innovative need for paradigms 
sinergie Vol. 33, N. 96, 2015

dependence on ecosystems and may simultaneously erode their ability to compete and even to operate. In that ecosystems provide the foundations for biological entities like humans - or other species - and organizations, we assume that ecosystem sustainability would have received higher priority than, or at least equivalent to, economic sustainability in the WCED framework (Gladwin et al., 1995; Starik and Rands, 1995). On the contrary, in the current and prevailing interpretation, economic development has precedence over environmental protection, which has simply become part of the development process (Banerjee, 2003). Therefore, there is an urgent need for an alternative paradigm based on a strong sustainability perspective and capable of recognizing that ecosystems and social systems are deeply interrelated. This new awareness could offer a more appropriate and effective theoretical framework that would allow us to successfully reframe markets and production processes in order to fit the logic of nature (Tencati et al., 2009).

\section{Going beyond "corporate greening"}

Starting from the pioneering works by Post (1991), Schmidheiny (1992), Shrivastava and Hart (1992), and Roome (1992), who first attempted to link management actions with societal and environmental challenges, business scholars have been struggling with the concept of sustainability, trying both to provide theoretical foundations for this emerging field of study, and to spur new independent and rigorous research (Bansal and Gao, 2006; Etzion, 2007). After more than two decades, the diffusion of concepts like "environmental management", "ecology", "greening" and "sustainability" within business literature has proven to be successful (Montiel and Delgado-Ceballos, 2014), although several critical voices contend how much these efforts have contributed to a more profound transformation of management while acknowledging the interconnection between organizations and nature discussed in the previous section (Kallio and Nordberg, 2006; Winn and Pogutz, 2013).

With regard to the world of business practice, since the 1992 United Nations Conference on Environment and Development the adoption of the SD concept has also fostered a process of reform and change in organizations. Environmental issues (e.g., protection of natural capital, reduction of energy consumption, pollution prevention and control, waste management, and so on) have become part of corporate missions and values, and a vast literature has documented how sustainability strategies have been developed by firms (Hart, 1995; Lovins et al., 1999). Similarly, the development of sustainable technologies and products (Hart and Milstein, 1999; Shrivastava, 1995), the diffusion of environmental management systems (European Commission, 2014; ISO, 2013), and the disclosure of environmental and social information through sustainability reports (KPMG International, 2013) seem to be increasingly relevant phenomena, involving multiple industrial and geographical contexts. Montiel and Delgado-Ceballos sustains that: "It is almost impossible to browse a company's website or its official reports 
without finding references to "sustainability" or "sustainable development" (2014, p. 1). Furthermore, several studies - both qualitative and quantitative - have underlined that, thanks to proactive and innovative environmental strategies, firms might gain competitive advantages in terms of efficiency/ cost savings, product differentiation and new products, strengthened reputation, and risk reduction (Ambec and Lanoie, 2008; Bansal and Kendall, 2000; Porter and van der Linde, 1995; Russo and Fouts, 1997). We can therefore conclude that sustainability issues have become part of the business environment and corporate jargon.

However, despite these greening efforts the overall ecological footprint of corporations has increased. Therefore, a key research question that management scholars have to address in the very next future is to what extent current environmental management practices are compatible with environmental sustainability (Banerjee 2003; Starik, 2006). If we want to build a sustainable pattern of development, business contribution is fundamental (Schmidheiny, 1992; Hart, 1995). So, from a managerial standpoint, we need to understand why present corporate behaviour is still profoundly inadequate and how we can contribute to the sustainability challenge.

First, corporate greening has mainly focused on the opportunities linked to the implementation of environmental strategies and to the competitive advantages associated with these initiatives. The notion of win-win solutions (Porter and van der Linde, 1995), which is at the core of the concept of eco-efficiency (Schmidheiny, 1992), has become the crucial issue in management practice, leading many corporations to important changes in their organizational routines. Most firms have worked on the direct impacts of their activities to minimize the pollutants of production processes and products, improve energy efficiency, and reduce risks. On the other hand, the idea that firms cannot grow indefinitely, but have to respect natural carrying capacity and ecosystem dynamics as a potential limit, has never been seriously taken into account, and the strong increases in volumes of production and sales of many firms have not been counterbalanced by improvements in eco-efficiency.

Most firms, practitioners and scholars in the management field have substantially integrated environmental issues into a "business as usual" approach instead of advancing a radical change in the deep nature of business and markets. Even now, after the financial downturn started in 2007, the mainstream economy is still characterized by short-termism and a competitive model where corporate success is pursued at the expense of nature, society and future generations (Zsolnai, 2006). Although such a critique is considered unrealistic and naïve by many, a pragmatic shift in company targets from eco-efficiency to eco-effectiveness (Dyllick and Hockerts, 2002) and towards a multiple-bottom-line perspective (Perrini et al., 2011; Perrini and Tencati, 2008; Tencati and Zsolnai, 2009) is necessary and might support the diffusion of more environmentally sustainable business models.

Second, until now corporate response to the environmental crisis has been mainly isolated and "egocentric" (Jennings and Zandbergen, 1995). Instead of focusing on collaborative relationships along the whole supply
Antonio Tencati

Recognizing the limits:

sustainable development

corporate sustain corporate sustainability innovative need for paradigms 
sinergie Vol. 33, N. 96, 2015

chain (from raw materials suppliers to consumers), many firms have concentrated their efforts on internal solutions aimed at reducing the direct environmental impact generated at the production site level. Furthermore, environmental risks are often isolated, while pollutants coming from many different sources and with various impacts have different time and spatial scales, impacting the resilience of multiple ecosystems (Folke, 2006).

The issue of linking ecosystems to business organizations is of central importance for the analysis of almost any action related to sustainable development. Therefore, environmental sustainability calls for holistic approaches (Golinelli, 2010) and firms have to implement environmental strategies through a "collaborative network" perspective (Frosch and Gallopoulos, 1989; Gallopoulos, 2006; Kelly, 1994; McDonough and Braungart, 2002).

\section{Towards sustainable business models: a conceptual framework}

To be truly environmentally sustainable a firm, besides respecting social requirements and producing economic value for its stakeholders, should not generate harm to the natural environment. This means that the firm would need to adapt to and align with the ecosystem dynamics where its multiple activities are embedded, as well as contribute to the preservation of the ecosystem services on which its business model strongly depends (Winn and Pogutz, 2013). This section advances a conceptual framework in order to provide scholars and practitioners with a lens to position and analyse the actions that firms are called to make to address the sustainability challenge. These efforts range from the attempt to optimize the environmental impact of production units, to redesigning products, services and supply chains, to the introduction of radically new business models (see Figure 1).

Indeed, these initiatives have different impacts on the organization, on its capacity to successfully compete in the business arena and to create enduring value for its stakeholders. At the same time, they require new knowledge and competencies that are not always available inside the firm.

The first group of actions focuses on production units and internal processes, and usually requires relatively limited organizational changes and investments. This is the case of companies that are managing sustainability mainly as an eco-efficiency challenge, following the Porter Hypothesis (Porter and van der Linde, 1995) and searching for the benefits deriving from an increase in resource productivity. Environmental management systems (ISO 14001 and the European Eco-Management and Audit Scheme - EMAS) usually support this phase, which is driven by technical departments and engineering competencies and promotes local optimization of environmental factors. This is the case, for example, of Pollution Prevention Pays, the program that 3M started in 1975. 
Fig. 1: Business efforts and actions towards sustainability: A conceptual framework

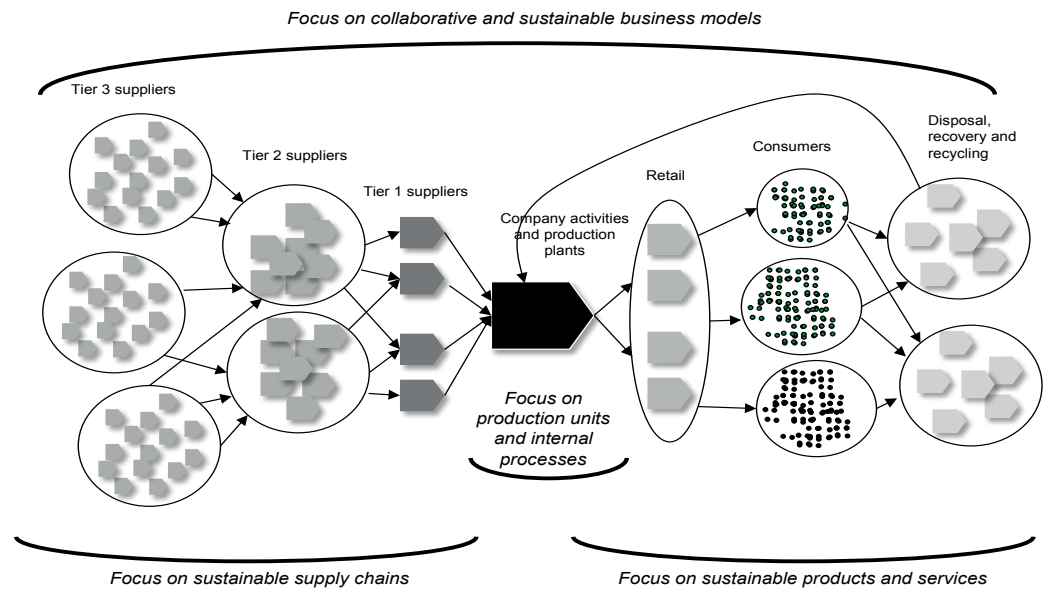

Antonio Tencati

Stefano Pogutz

Recognizing the limits: sustainable development, sustainability innovative need for paradigms

Source: Authors' elaboration

The second set of initiatives refers to designing sustainable products and services. This approach extends the notion of corporate sustainability downstream, towards the final consumers and the recovery/recycling of the product at the end of its life-cycle. These actions require a much more profound transformation of the organizational culture since they involve the marketing function and modify the product-system and the relation with final consumers. The growing market segment of Lifestyles of Health and Sustainability (LOHAS) consumers in the US and Europe, and an increasing attention towards green brands provide the base for successful green differentiation (Kotler, 2011; Reinhardt, 1998). There are several cases of companies that are trying to win these new market segments or consolidate their reputation and brand value by greening their offer. Examples are Timberland "Earthkeepers" campaign, or General Electric "Ecomagination" program.

At the same time, through designing energy-efficient products and eco-efficient packaging or eliminating potentially harmful substances the company responds to environmental challenges in a much more convincing way. It is broadly known, in fact, among scholars dealing with business sustainability, that a large part of the environmental impact in many product categories (up to $80 \%$ in the case of durable goods like cars, household appliances, electronics) occurs during the consumption phase or after the products' disposal, therefore when the goods are transferred to their consumers. Focusing downstream allows companies to significantly reduce their environmental footprint.

The third approach regards the development of sustainable supply chains (Linton et al., 2007; Sarkis, 2003). Few companies have extended the sustainability focus upstream, to the very early stage of the raw material production. In any case, for some typologies of environmentally-intensive commodities corporate risks are sharply increasing due to resource scarcity, market prices and stakeholder pressures. At the same time, for several 
Sinergie Vol. 33, N. 96, 2015

industries the environmental footprint very much depends on the impact generated by second-, third- or even fourth-tier suppliers. Puma has introduced a new method to measure the impact generated by its extended supply chain. The results revealed that $57 \%$ of the environmental impact occurred at the raw material production level, while only $6 \%$ of the impact derived from Puma's operations (Meyers and Waage, 2014). The response in these cases involved a thoughtful re-design of the supply chain that goes well beyond putting some "sustainable development" into purchasing or introducing some code of conduct into the relation with first-tier suppliers. Unilever provides another example. The AngloDutch company has focused on Lipton, one of the most important brands with over $€ 3.5$ billion revenues, and has developed a partnership with an independent NGO specialized in certifying sustainable farming activities, Rainforest Alliance, to deploy an ambitious plan aiming at transforming the tea supply chain into 100\% sustainable sourcing by 2015 (Henderson and Nellemann, 2011). Another interesting example is the Sustainable and Integrated Supply Chain program introduced by Barilla. The Italian "pasta company" is targeting a reduction of the overall environmental footprint through the implementation of a series of initiatives in partnership with its farmers. These actions include the introduction of innovative cropping practices that favour an improvement in the productivity of the land, coupled with a relevant reduction in the use of fertilizers, pesticides and water (up to 30-35\%) (BCFN and Barilla, 2013).

Finally, the fourth level consists in the development of radically new business models grounded in the acknowledgment that the challenge of sustainability asks for path-breaking solutions and requires profound transformations in the way companies are doing business. In several industries over the last couple of decades, companies relying on old business-models have been threatened and challenged by innovative ones that have quickly transformed the "rules of the game". Examples are copious: the decline of print in the media; online shopping in retail; digital music services like Spotify and platforms like iTunes in music; online banking in finance. Managers and entrepreneurs are unceasingly required to find new ways to create and deliver value to final consumers. The sustainability challenge is of course ambitious and risky for a company but it can offer new opportunities to compete, transforming the industry and leading to the greatest environmental and economic results. Well known examples in sustainability management literature include companies like Patagonia, the outdoor-clothing brand founded by the environmental "guru" Yvon Chouinard who has devoted decades to the business of sustainability, or Natura, the leading Brazilian producer of natural cosmetics. Novel examples are related to the diffusion of organic products in sectors like food and textile, or the sharp growth of renewable resources that are shaking the electricity industry in several countries. When resources turn out not to be limitless as they were considered until few years ago and when the idea of endless consumption is no longer affordable, business model innovation might have real system effects, redefining the relations between ecosystems and companies and between humans and nature. 
To conclude, most firms still compete considering environmental issues no more than a "cost", or by focusing on the local optimization of pollution emissions according to a compliance approach. In contrast, some large multinationals such as Unilever, Walmart, General Electric, Starbucks, and Toyota have embraced sustainability as a key business challenge and have developed multiple initiatives that combine on-site efficiency with green design and more sustainable supply chains. This is an important step towards a cleaner planet. As previously illustrated, however, in our view a much more profound transformation is needed if we want to address the environmental crisis, harmonizing our production and consumption patterns with ecosystem dynamics and the limits of nature.

\section{Conclusions: the need for a paradigm change}

In the previous paragraphs we have outlined the conditions which make the current patterns of development unsustainable worldwide. Building on that we tried to challenge the current assumptions which underpin the mainstream paradigm in the management field. In order to do that we have drawn on natural science and ecological economics concepts to provide a more credible and reliable view of the functioning mechanisms characterizing natural capital and its interdependency with business practices.

This innovative approach calls for a redefinition of the prevailing business models which are unable to recognize the biophysical limits of the ecosystems in which firms operate. Therefore we introduced a conceptual framework to systematize the different types of actions that are needed in order to address the sustainability challenge.

In particular, distributed systems of energy production, enabled by local renewables and smart grids, short supply chains and local food economies, zero-emission transport systems, and waste management policies focused on prevention and supported by an effective recycling/recovery industry are all examples of innovative solutions, which require, in any case, new paradigms and approaches. Only the implementation of shared and participated strategies among different players can promote the diffusion of these innovative practices and technologies.

So, what are the lines of action required to really overcome the current unsustainable paradigm? How can we initiate a transformational change (WWF-UK, 2011) that is coherent with a more balanced and interlinked view of the economic, social and environmental dimensions of development? How can we support innovative business models and system innovation (Tukker et al., 2008)? We acknowledge that the answers to the previous questions go beyond the aim of this contribution, but it is possible to outline four areas of intervention and research - firms, markets, civil society and policy makers - as key drivers of change.

Firms. With regard to the firm level, the one dimensional shareholder value approach has demonstrated to be unable to provide effective responses to the ecological and social crisis. A more comprehensive way
Antonio Tencati
Stefano Pogutz

Recognizing the limits: sustainable development corporate sustainability innovative need for paradigms 
sinergie Vol. 33, N. 96, 2015

to measure and assess corporate performance that includes contribution to the "common good" (Jackson, 2012) is therefore required. In parallel, instead of a traditional self-defeating competitive view, a collaborative perspective in business practices could further strengthen more durable processes of value creation capable of rewarding, in different ways, all the constituencies affected by - and involved in - corporate activities (Tencati and Zsolnai, 2009). A new set of key performance indicators (KPIs), capable of intercepting social and environmental impacts, represents a pivotal change in order to align business with sustainability challenges. Furthermore, these KPIs should be embedded into MBO (i.e., management by objectives) systems to foster coherent managerial decision making processes. This kind of non-financial information is needed in order to integrate and complement the traditional financial measures that are clearly unable to assess the quality of management and that provide incentives that are not in line with sustainable targets.

Markets. To overcome the short-termism of financial markets a broader concept of value creation that also takes social, environmental and governance (ESG) issues into account, is necessary. The emerging phenomenon of integrated reporting, the well-established socially responsible investing (SRI) movement, the increasing shareholder activism, and initiatives such as the Carbone Disclosure Project, are forcing firms to adopt higher standards in the accountability field, shifting the corporate focus from the shareholder value idea to a multi-dimensional concept of stakeholder value. These dynamics need to be sustained and further strengthened in order to broadly diffuse in the markets, affect investor behaviour, and impact on the financial community at large.

Civil society. Advocacy groups and nongovernmental organizations have become key forces in the societal environment that are capable of affecting firm behaviour directly and indirectly (e.g., exercising pressure on consumers, media, and policy makers). At the same time, thanks to their specialized knowledge, skills and capabilities civil society groups offer firms critical resources in order to tackle social and environmental issues. Cross-sector forms of collaboration between firms and civil society represent a growing phenomenon which, according to many observers, might support business transformation towards more sustainable approaches (Seitanidi and Crane, 2014).

Policy makers. New policies and regulations are required to foster transformations that change the rules of the game. A recent example of this is represented by the introduction of new requirements with regard to non-financial reporting in several countries and - especially in the European Union - with the recent issue of the European Directive on this topic. Another area where public interventions are crucial is action on climate change. In fact, the attention of the public opinion is concentrated on the expected outcomes of the next United Nations Conference of the Parties in Paris, which will be held at the end of 2015.

Table 2 presents a summary of possible lines of action and related emerging research issues that could support a positive transition. 
Tab. 2: Transition towards a new paradigm: Actions and emerging research issues

\begin{tabular}{|c|c|c|}
\hline Areas & Examples of actions & Emerging research issues \\
\hline Firms & $\begin{array}{l}\text { - Introduction of targeted } \\
\text { KPIs according to a multiple- } \\
\text { bottom-line perspective } \\
\text { - Revision of MBO systems for } \\
\text { advanced decision-making } \\
\text { processes }\end{array}$ & $\begin{array}{l}\text { - What is the real meaning of the } \\
\text { value creation concept? } \\
\text { - How can we promote a } \\
\text { collaborative attitude in business } \\
\text { that is capable of developing } \\
\text { sustainable value creation } \\
\text { processes? } \\
\text { - How can we favour the } \\
\text { establishment and development of } \\
\text { flourishing organizations (Laszlo } \\
\text { et al., 2014)? }\end{array}$ \\
\hline Markets & $\begin{array}{l}\text { - From shareholder to } \\
\text { stakeholder value under the } \\
\text { pressure of several converging } \\
\text { factors (for example, SRI, } \\
\text { shareholder activism, new } \\
\text { forms of accountability such } \\
\text { as integrated reporting, and so } \\
\text { on) }\end{array}$ & $\begin{array}{l}\text { - How can markets become agents } \\
\text { of change driving sustainability? } \\
\text { - How can short-termism be } \\
\text { replaced by a more consistent and } \\
\text { coherent long-term view? What } \\
\text { types of market incentives can } \\
\text { support this transition? }\end{array}$ \\
\hline $\begin{array}{l}\text { Civil } \\
\text { society }\end{array}$ & $\begin{array}{l}\text { - Development of cross-sector } \\
\text { partnerships towards more } \\
\text { sustainable approaches }\end{array}$ & $\begin{array}{l}\text { What are the enabling conditions } \\
\text { to foster cross-sector partnerships? } \\
\text { - How can different interests and } \\
\text { perspectives converge in effective } \\
\text { multi-stakeholder networks to } \\
\text { drive advanced and innovative } \\
\text { policies? }\end{array}$ \\
\hline $\begin{array}{l}\text { Policy } \\
\text { makers }\end{array}$ & $\begin{array}{l}\text { - New policies and regulations } \\
\text { to change the rules of the } \\
\text { game: e.g., non-financial } \\
\text { reporting and action on } \\
\text { climate change }\end{array}$ & $\begin{array}{l}\text { - What new types of governance } \\
\text { are required to address global and } \\
\text { complex sustainability challenges? } \\
\text { - What new tools are needed to } \\
\text { lead the change, considering, for } \\
\text { example, the failure of current } \\
\text { environmental policies? }\end{array}$ \\
\hline
\end{tabular}

Source: Authors' elaboration

To conclude, the challenge of SD entails questioning the roots of the mainstream, competitive paradigm and developing really innovative alternatives based on a deep and genuine respect for nature and all parties involved. This should lead to system innovations based on a collaborative approach and the interaction among firms, public authorities and civil society to address sustainability issues.

Therefore, the still prevailing unsustainable attitudes in business should be reoriented towards more caring and collaborative models (see Table 3).
Antonio Tencati Stefano Pogutz

Recognizing the limits: sustainable development,

corporate sustainability corporate sustainability innovative need for paradigms 
sinergie Vol. 33, N. 96, 2015
Tab. 3: Mainstream enterprises versus collaborative enterprises

\begin{tabular}{|l|l|l|}
\hline & Mainstream Enterprises & Collaborative Enterprises \\
\hline $\begin{array}{l}\text { Basic } \\
\text { motive }\end{array}$ & Self-interest & $\begin{array}{l}\text { Care about others } \\
\text { and themselves }\end{array}$ \\
\hline Main goal & $\begin{array}{l}\text { Maximizing profit or } \\
\text { shareholder value }\end{array}$ & $\begin{array}{l}\text { Creating values for all the } \\
\text { participants in the network } \\
\text { (including the natural } \\
\text { environment) }\end{array}$ \\
\hline $\begin{array}{l}\text { Criterion of } \\
\text { success }\end{array}$ & Growth in monetary terms & $\begin{array}{l}\text { Mutually beneficial relationships } \\
\text { with stakeholders (including the } \\
\text { natural environment) }\end{array}$ \\
\hline
\end{tabular}

Source: Adapted from Tencati and Zsolnai (2014, p. 321)

Enterprises can be extraordinary forces for good (Birkinshaw and Piramal, 2005) when they are able to overcome old habits and deeply care about others (including nature, society, and future generations) thanks to broad and sustainable value creation processes.

\section{References}

AMBEC S., LANOIE P. (2008), "Does it pay to be green? A systematic overview", Academy of Management Perspectives, vol. 22, n. 4, pp. 45-62.

ARROW K., BOLIN B., COSTANZA R., DASGUPTA P., FOLKE C., HOLLING C.S., JANSSON B.O., LEVIN S., MÄLER K.G., PERRINGS C., PIMENTEL D. (1995), "Economic growth, carrying capacity, and the environment", Science, vol. 268, n. 5210, pp. 520-521.

AYRES R.U. (2007), “On the practical limits to substitution”, Ecological Economics, vol. 61, n. 1, pp, 115-28.

BANERJEE S.B. (2003), "Who sustains whose development? Sustainable development and the reinvention of nature", Organization Studies, vol. 24, n. 1, pp. 143-180.

BANSAL P., GAO J. (2006), "Building the future by looking to the past examining research published on organizations and environment", Organization and Environment, vol. 19, n. 4, pp. 458-478.

BANSAL P., KENDALL R. (2000), "Why companies go green: A model of ecological responsiveness", Academy of Management Journal, vol. 43, n. 4, pp. 717-736.

BCFN (BARILLA CENTER FOR FOOD AND NUTRITION), BARILLA (2013), Sustainable durum wheat in Italy - Farming Barilla 2010/13, Working Paper, Barilla, Parma.

BIRKINSHAW J., PIRAMAL G., (eds.), (2005), Sumantra Ghoshal on management: A force for good, Prentice Hall, Harlow.

CAPRA F. (1996), The web of life: a new scientific understanding of living systems, Anchor Books, New York. 
CHIESURA A., DE GROOT R., (2003), "Critical natural capital: a socio-cultural perspective”, Ecological Economics, vol. 44, n. 2/3, pp. 219-231.

COSTANZA R. (1991), Ecological economics: The science and management of sustainability, Columbia University Press, New York.

COSTANZA R., D’ARGE R., DE GROOT R., FARBER S., GRASSO M., HANNON B., LIMBURG K., NAEEM S., O’NEILL R.V., PARUELO J., RASKIN R.G., SUTTON P., VAN DEN BELT M. (1997), “The value of the world's ecosystem services and natural capital”, Nature, vol. 387, 15 May, pp. 253-260.

CREDIT SUISSE AG RESEARCH INSTITUTE (2014), Global Wealth Databook 2014, Credit Suisse AG Research Institute, Zurich, https://publications. credit-suisse.com/tasks/render/file/?fileID $=5521 \mathrm{~F} 296-\mathrm{D} 460-2 \mathrm{~B} 88$ 081889DB12817E02.

CROUCH C. (2011), The strange non-death of neoliberalism, Polity Press, Cambridge, UK.

CRUTZEN P.J. (2002), “Geology of mankind”, Nature, vol. 415, n. 3 January, p. 23.

DALY H.E. (1992), Steady-state economics, Earthscan Publications, London.

DODDS S. (1995), Understanding sustainable development: a policy oriented guide to the idea and its application, CRES working paper 1995/1, Australian National University, Canberra.

DYLLICK T., HOCKERTS K. (2002), "Beyond the business case for corporate sustainability", Business Strategy and the Environment, vol. 11, n. 2, pp. 130141.

EKINS P., FOLKE C., DE GROOT R. (2003a), "Identifying critical natural capital", Ecological Economics, vol. 44, n. 2-3, pp. 159-163.

EKINS P., SIMON S., DEUTSCH L., FOLKE C., DE GROOT R. (2003b), “A framework for the practical application of the concepts of critical natural capital and strong sustainability", Ecological Economics, vol. 44, n. 2.3, pp. 165-185.

ELKINGTON J. (1994), “Towards the sustainable corporation: Win-win-win business strategies for sustainable development", California Management Review, vol. 36, n. 2, pp. 90-100.

ETZION D. (2007), "Research on organizations and the natural environment, 1992-present: A review”, Journal of Management, vol. 33, n. 4, pp. 637-664.

EUROPEAN COMMISSION (2014), EMAS Register, http://ec.europa.eu/ environment/emas/registration/sites_en.htm.

FAO (FOOD AND AGRICULTURE ORGANIZATION OF THE UNITED NATIONS), IFAD (INTERNATIONAL FUND FOR AGRICULTURAL DEVELOPMENT), WFP (WORLD FOOD PROGRAMME) (2013), The state of food insecurity in the world 2013. The multiple dimensions of food security, FAO, Rome.

FOLKE C. (2006), "Resilience: The emergence of a perspective for social-ecological systems analyses", Global Environmental Change, vol. 16, n. 3, pp. 253-267.

FROSCH R.A., GALLOPOULOS N.E. (1989), "Strategies for manufacturing", Scientific American, vol. 261, n. 3, pp. 144-152.

GALlOPOULOS N.E. (2006), "Industrial ecology: an overview", Progress in Industrial Ecology - An International Journal, vol. 3, n. 1/2, pp. 10-27.

GHOSHAL S. (2005), "Bad management theories are destroying good management practices", Academy of Management Learning and Education, vol. 4, n. 1, pp. 75-91.
Antonio Tencati

Stefano Pogutz

Recognizing the limits:

sustainable development,

corporate sustainability

corporate sustainability innovative need for paradigms 
sinergie Vol. 33, N. 96, 2015

GLADWIN T.N., KENNELLY J.J., KRAUSE T.S. (1995), "Shifting paradigms for sustainable development: Implications for management theory and research", Academy of Management Review, vol. 20, n. 4, pp. 874-907.

GOLINELLI G.M., (2010), Viable systems approach (VSA). Governing business dynamics, Cedam, Padova.

GOLINELLI G.M., VOLPE L. (2012), Consonanza, valore, sostenibilità. Verso l'impresa sostenibile, Cedam, Padova.

HART S.L. (1995), "A natural-resource-based view of the firm”, Academy of Management Review, vol. 20, n. 4, pp. 986-1014.

HART S.L., MILSTEIN M.B. (1999), "Global sustainability and the creative destruction of industries", Sloan Management Review, vol. 41, n. 1, pp. 23-33.

HENDERSON R.M., NELLEMANN F. (2011), "Sustainable tea at Unilever", Harvard Business School Case, n. 712-438, December 2011.

HOLLING C.S. (2001), "Understanding the complexity of economic, ecological, and social systems", Ecosystems, vol. 4, n. 5, pp. 390-405.

IPCC (Intergovernmental Panel on Climate Change) (2013), Working Group I - Contribution to the IPCC fifth assessment report. Climate change 2013: The physical science basis - Summary for policymakers, http://www. climatechange2013.org/images/report/WG1AR5_SPM_FINAL.pdf.

ISO (International Organization for Standardization) (2013), The ISO survey of management system standard certifications - 2012, ISO, Geneva, http://www.iso.org/iso/home/standards/certification/iso-survey. htm? certificate $=\mathrm{ISO} \% 209001 \&$ countrycode $=\mathrm{AF}$.

JACKSON K.T. (2012), Virtuosity in business: Invisible law guiding the invisible hand, University of Pennsylvania Press, Philadelphia.

JENNINGS P.D., ZANDBERGEN P.A. (1995), "Ecologically sustainable organizations: An institutional approach", Academy of Management Review, vol. 20, n. 4, pp. 1015-1052.

KALLIO T.J., NORDBERG P. (2006), "The evolution of organizations and natural environment discourse”, Organization and Environment, vol. 19, n. 4, pp. 439-457.

KELLY K. (1994), Out of control. The new biology of machines, social systems, and the economic world, Addison-Wesley, Boston.

KOTLER P. (2011), "Reinventing marketing to manage the environmental imperative", Journal of Marketing, vol. 75, n. 4, pp. 132-135.

KPMG International (2013), The KPMG survey of corporate responsibility reporting 2013, KPMG International, Amstelveen.

LASZLO C., BROWN J.S., EHRENFELD J.R., GORHAM M., BARROS POSE I., ROBSON L., SAILLANT R., SHERMAN D., WERDER P. (2014), Flourishing enterprise: The new spirit of business, Stanford University Press, Stanford.

LEVIN S.A. (2009), The Princeton guide to ecology, Princeton University Press, Princeton.

LINTON J.D., KLASSEN R., JAYARAMAN V. (2007), "Sustainable supply chains: An introduction”, Journal of Operations Management, vol. 25, n. 6, pp. 1075-1082.

LOVINS A.B., LOVINS L.H., HAWKEN P. (1999), "A road map for natural capitalism”, Harvard Business Review, vol. 77, n. 3, pp. 145-158. 
MARTINEZ-ALIER J., SCHUPMANN K. (1987), Ecological economics: energy, environment and society, Blackwell, Oxford.

MCDONOUGH W., BRAUNGART M. (2002), Cradle to cradle: remaking the way we make things, North Point Press, New York.

MEA (MILLENNIUM ECOSYSTEM ASSESSMENT) (2005), Ecosystems and human well-being: Opportunities and challenges for business and industry, World Resources Institute, Washington, DC, http://www.maweb.org/documents/ document.353.aspx.pdf.

MEYERS D., WAAGE S. (2014), "Environmental profit and loss: The new corporate balancing act", 18 February, http://www.greenbiz.com/blog/2014/02/18/ environmental-profit-and-loss-new-corporate-balancing-act.

MONTIEL I., DELGADO-CEBALLOS J. (2014), "Defining and measuring corporate sustainability. Are we there yet?", Organization and Environment, 4 April, http://oae.sagepub.com/content/early/2014/04/03/1086026614526413.

PASCUCCI F. (2011), "Responsabilità sociale e questione etica nell'impresa: alcune riflessioni”, Sinergie, n. 86, pp. 133-150.

PEARCE D.W., TURNER R.K. (1990), Economics of natural resources and the environment, The Johns Hopkins University Press, Baltimore.

PERRINI F., RUSSO A., TENCATI A., VURRO C. (2011), "Deconstructing the relationship between corporate social and financial performance", Journal of Business Ethics, vol. 102, Supplement 1, pp. 59-76.

PERRINI F., TENCATI A. (2008), "La responsabilità sociale d'impresa: strategia per l'impresa relazionale e innovazione per la sostenibilità', Sinergie, n. 77, pp. 23-43.

PORTER M.E., VAN DER LINDE C. (1995), “Green and competitive: Ending the stalemate", Harvard Business Review, vol. 73, n. 5, pp. 120-134.

POST J.E. (1991), "Managing as if the earth mattered", Business Horizons, vol. 34, n. 4, pp. 32-38.

REINHARDT F.L. (1998), "Environmental product differentiation: Implications for corporate strategy", California Management Review, vol. 40, n. 4, pp. 43-73.

ROCKSTRÖM J., STEFFEN W., NOONE K., PERSSON Å., CHAPIN F.S. III, LAMBIN E.F., LENTON T.M., SCHEFFER M., FOLKE C., SCHELLNHUBER H.J., NYKVIST B., DE WIT C.A., HUGHES T., VAN DER LEEUW S., RODHE H., SÖRLIN S., SNYDER P.K., COSTANZA R., SVEDIN U., FALKENMARK M., KARLBERG L., CORELL R.W., FABRY V.J., HANSEN J., WALKER B., LIVERMAN D., RICHARDSON K., CRUTZEN P. FOLEY J.A. (2009), “A safe operating space for humanity”, Nature, vol. 461, 24 September, pp. 472475.

ROOME N. (1992), "Developing environmental management strategies", Business Strategy and the Environment, vol. 1, n. 1, pp. 11-24.

RUSSO M.V., FOUTS P.A. (1997), "A resource-based perspective on corporate environmental performance and profitability", Academy of Management Journal, vol. 40, n. 3, pp. 534-559.

SARKIS J. (2003), "A strategic decision framework for green supply chain management", Journal of Cleaner Production, vol. 11, n. 4, pp. 397-409.

SCHMIDHEINY S. (1992), Changing course: a global business perspective on development and the environment, MIT Press, Cambridge, MA.

SEIDL I., TISDELL C.A. (1999), "Carrying capacity reconsidered: From Malthus' population theory to cultural carrying capacity", Ecological Economics, vol. 31, n. 3, pp. 395-408.
Antonio Tencati

Stefano Pogutz

Recognizing the limits:

sustainable development,

corporate sustainability and the need for innovative paradigms 
Sinergie Vol. 33, N. 96, 2015

SEITANIDI M.M., CRANE A., (eds.), (2014), Social partnerships and responsible business: A research handbook, Routledge, Abingdon-New York.

SHRIVASTAVA P. (1995), "Environmental technologies and competitive advantage", Strategic Management Journal, vol. 16, n. S1, pp. 183-200.

SHRIVASTAVA P., HART S. (1992), "Greening organizations", Academy of Management Best Paper Proceedings, August 1, pp. 185-189.

SNEDDON C., HOWARTH R.B., NOTGARD R.B. (2006), "Sustainable development in a post-Brundtland world", Ecological Economics, vol. 57, n. 2, pp. 253-268.

SOLOW R.M. (1986), "On the intergenerational allocation of natural resources", Scandinavian Journal of Economics, vol. 88. n. 1, pp. 141-149.

STARIK M. (2006), "In search of relevance and impact", Organization and Environment, vol. 19, n. 4, pp. 431-438.

STARIK M., RANDS G.P. (1995), "Weaving an integrated web: Multilevel and multisystem perspectives of ecologically sustainable organizations", Academy of Management Review, vol. 2, n. 4, pp. 908-935.

STIGLITZ J.E. (2012), The Price of inequality: How today's divided society endangers our future, W.W. Norton \& Company, New York-London.

TENCATI A., POGUTZ S. (2011), "Respect for nature: The need for innovative business patterns", in Jakobsen O.D., Pedersen L.J.T., (eds.), Responsibility, deep ecology and the self: Essays in honor of Knut J. Ims on his 60th Anniversary, Forlag 1, Oslo.

TENCATI A., POGUTZ S., ROMERO C (2009), "Achieving environmental sustainability", in Zsolnai L., Tencati A., (eds.), The future international manager: A vision of the roles and duties of management, Palgrave Macmillan, Houndmills and New York.

TENCATI A., ZSOLNAI L. (2009), “The collaborative enterprise”, Journal of Business Ethics, vol. 85, n. 3, pp. 367-376.

TENCATI A., ZSOLNAI L. (2014), "Towards a new theory of the firm: The collaborative enterprise", in Seitanidi M.M., Crane A., (eds.), Social partnerships and responsible business: A research handbook, Routledge, Abingdon-New York.

THE ECONOMIST (2011), "Rage against the machine", The Economist, 22 October, p. 13.

TUKKER A., CHARTER M., VEZZOLI C., STØ E., ANDERSEN M.M., (eds.), (2008), System innovation for sustainability 1. Perspectives on radical changes to sustainable consumption and production, Greenleaf Publishing, Sheffield.

UNITED NATIONS (2013), The Millennium Development Goals Report 2013, United Nations, New York, http://www.un.org/millenniumgoals/pdf/ report-2013/mdg-report-2013-english.pdf.

WCED (World Commission on Environment and Development) (1987), Our Common Future, Oxford University Press, Oxford, http://www.undocuments.net/wced-ocf.htm.

WINN M.I., POGUTZ S. (2013), "Business, ecosystems, and biodiversity. New horizons for management research", Organization and Environment, vol. 26, n. 2, pp. 203-229.

WWF (World Wide Fund for Nature) (2014), Living Planet Report 2014: species 
and spaces, people and places, WWF International, Gland, http://wwf.panda. org/about_our_earth/all_publications/living_planet_report/.

Antonio Tencati Stefano Pogutz

Recognizing the limits:

sustainable development,

WWF-UK (2011), More CEOs join call for transformational change, 20 June, http:// www.wwf.org.uk/what_we_do/press_centre/?5022/More_CEOs_join_call_ $\begin{gathered}\text { and the } \\ \text { innovative } \\ \text { paradigms }\end{gathered} \begin{gathered}\text { need for } \\ \text { business }\end{gathered}$ corporate sustainability for_transformational_change.

ZSOLNAI L. (2006), "Extended stakeholder theory", Society and Business Review, vol. 1, n. 1, pp. 37-44.

\title{
Academic or professional position and contacts
}

\author{
Antonio Tencati \\ Associate Professor of Management \\ University of Brescia, Italy \\ e-mail: antonio.tencati@unibs.it
}

\section{Stefano Pogutz}

Tenured Researcher of Management

Bocconi University, Milan, Italy

e-mail: stefano.pogutz@unibocconi.it

sinergie

ISSN 0393-5108 DOI 10.7433/s96.2015.03 